\title{
GEOLOGIC MAP OF THE SCOTT CITY 7.5-MINUTE QUADRANGLE, SCOTT AND CAPE GIRARDEAU COUNTIES, MISSOURI
}

\author{
By Richard W. Harrison, ${ }^{1}$ James R. Palmer, ${ }^{2}$ David Hoffman, ${ }^{2}$ James D. Vaughn, ${ }^{2}$ \\ John E. Repetski, ${ }^{1}$ Norman O. Frederiksen, ${ }^{1}$ and Steven L. Forman ${ }^{3}$
}

\section{DISCUSSION}

\section{GEOMORPHOLOGY AND SURFICIAL GEOLOGY}

The Scott City quadrangle is located at the northern end of the Mississippi embayment (fig. 1). The quadrangle contains parts of three physiographic features: the abandoned channel of the ancestral Mississippi River, the Benton Hills, and the flood plain of the ancestral Ohio River and modern Mississippi River. These features are largely the manifestation of the Quaternary evolution of the Mississippi and Ohio Rivers, the chronology and analysis of which has been discussed by Fisk (1944), Saucier (1968, 1974, 1994), Guccione and others (1990), Madole and others (1991), Autin and others (1991), Porter and Guccione (1994), and Blum and others (1995a,b).

The relatively flat area in the northern part of the quadrangle is part of the abandoned Mississippi River channel that was active prior to the river's diversion through Thebes Gap in the adjacent Thebes 7.5-min quadrangle at approximately $10.6 \mathrm{ka}$ (Porter and Guccione, 1994). This area periodically is inundated by Mississippi River floods, except for the land protected by a manmade levy (af) maintained by the U.S. Army Corps of Engineers. Within the abandoned channel, alluvial-fan deposits (Qaf) derived from the surrounding uplands have prograded over alluvial fill $(\mathrm{Oma})$. The bedrock outcrops at Lost Hill and an adjacent hill in sec. 4, T. 29 N., R. 13 E., were former islands in the ancestral Mississippi River.

The uplands area that makes up most of the quadrangle is part of the Benton Hills, the northernmost extension of Crowley's Ridge (fig. 1). Geometrically, the Benton Hills resemble a tilted block dipping to the north-northwest. The highest topography in the Benton Hills occurs at the extreme southeastern margin along a drainage divide between the modern Mississippi River flood plain to the southeast and the severely underfit Ramsey and Caney Creeks. Stream-gradient profiles along Ramsey and Caney Creeks indicate that their original headwaters were removed by either erosional or tectonic processes (Palmer and Hoffman, 1993). These two creeks, as well as Sals Creek, provide surface drainage to the north and west for this part of the Benton Hills; all contain extensive Pleistocene terrace deposits (Ot) that are mantled by loess (dominantly Peoria) producing a subdued topographic expression. The towns of Scott City and Illmo are partly situated on a paleo-channel of the ancestral Mississippi River, which also contains loess-mantled terrace deposits on grade with those in Ramsey Creek.

In the extreme southeastern corner of the quadrangle, the small

1U.S. Geological Survey, Reston, VA 20192.

2Missouri Department of Natural Resources, Geological Survey and Resource Assessment Division, Rolla, MO 65401

3The University of Illinois at Chicago, Chicago, IL 60607. part of the modern Mississippi River flood plain is present as the Sandy Woods terrace (Oto), which was deposited by the ancestral Ohio River prior to the diversion of the Mississippi River through Thebes Gap. Alluvial-fan deposits (Oaf) derived from the Benton Hills have prograded over this terrace.

\section{GENERAL STRUCTURAL GEOLOGY}

Cretaceous and Tertiary coastal plain sediments pinchout in an approximately east-west direction across the Scott City quadrangle. This pinchout is an irregular, erosional line from which the coastal plain sediments thicken towards the south and lie with angular unconformity upon a lower Paleozoic platform sequence of carbonate and lesser siliciclastic rocks that regionally dip and thicken into the Illinois basin to the northeast. Thus, the oldest exposed Paleozoic unit, the Everton Formation, crops out in the southwestern corner of the quadrangle, and the youngest Paleozoic unit, the Plattin Group, crops out in the northeastern part of the quadrangle.

The Scott City quadrangle is approximately 15 to $20 \mathrm{mi}$ north of the New Madrid seismic zone (fig. 1) and has experienced moderate recent seismic activity (Stover and Brewer, 1991; Chiu, 1991; Herrmann, 1993). Recorded epicenters of earthquakes since 1989 are shown on the geologic map as solid triangles. A body-wavemagnitude 4.5 event occurred on September 26, 1990 (900926) in sec. 23 , T. 29 N., R. $13 \mathrm{E}$., and is the largest event recorded in the midcontinent during the 1990's.

A prominent geophysical lineament in the Precambrian magnetic basement, the Commerce geophysical lineament (fig. 1), first was identified by Hildenbrand and Hendricks (1995). It lies directly beneath the English Hill area in the extreme southeastern corner of the quadrangle. This feature extends to both northeast and southwest for several hundreds of miles and is possibly related to recent earthquakes (Harrison and Schultz, 1994; Langenheim and Hildenbrand, 1997).

A system of northeast-trending faults is thought to exist throughout most of the quadrangle. However because of the extensive cover of windblown Quaternary loess, the only direct indication of these faults at the surface is in the southeastern part of the quadrangle, particularly the English Hill area (see fig. 4 and following section). Evidence for the widespread existence of these faults comes from (1) geologic mapping of the adjacent Thebes 7.5-min quadrangle where many of the faults are exposed (Harrison, 1999); (2) exposed faults in the adjacent Morley quadrangle to the south (R.W. Harrison, unpub. mapping, 1996); (3) seismic-reflection profiles acquired in the southeastern quarter of the quadrangle (Palmer and others, 1997a,b); (4) recorded seismic activity attributed to the area (Herrmann, 1993); and (5) drill-hole data that indicate significant offsets of stratigraphic horizons (see cross section $A-A$ ). Overall motion on the northeast-striking fault system is assumed to 
be dominantly right-lateral strike slip, as that is the dominant motion interpreted for faulting in the adjacent Thebes quadrangle (Harrison, 1999; Harrison and Schultz, 1994; Harrison and others, 1999) and for faults revealed by fault-exploration trenches in the English Hill area.

Although the overall fault system strikes northeasterly, faultexploration trenches and some natural exposures at English Hill and elsewhere in the Benton Hills show that deformation was complex and the fault zones contain many subsidiary structures that have extensional, contractional, and strike-slip components (Harrison and others, 1997; Harrison and others, 1999). In addition, multiple episodes of deformation occurred throughout most of the Phanerozoic, including the Quaternary (Harrison and Schultz, 1994; Harrison and others, 1999).

Buried faults shown on the geologic map are located approximately and are very simplified. Alignment of some drainages may reflect the location of some buried faults, particularly segments of the Grays Point Quarry, Mile 46, and Rose Creek faults. Possible surface expression of an unnamed northeast-striking fault in secs. 15,16 , and 21, T. 29 N., R. 13 E. occurs as the alignment of topographic saddles. Apparent offsets of McNairy Sand and Mounds Gravel also suggest the existence of this fault.

At Lost Hill in sec. 4, T. 29 N., R. 13 E., an intense zone of cataclastic shears occurs in the St. Peter Sandstone. Development of cataclastic shears, or deformation bands, is the preferred deformational mechanism in porous granular materials (Aydin, 1978; Aydin and Johnson, 1978; Jamison and Stearns, 1982; Antonellini and others, 1994; and Davis, 1999) such as the St. Peter Sandstone. Formation of cataclastic shears is marked by granulation and cataclasis, which results in reduction of porosity and imparts a visual resemblance to veins. Typically, these shears are not expressed as discrete fracture surfaces. Orientations of cataclastic shears at Lost Hill are highly variable, however, a dominant northwesterly trend exists (fig. 2); many occur along bedding planes. Cataclastic shears have been cut by open fractures that strike from N. $45^{\circ}-55^{\circ} \mathrm{E}$., dip steeply both to the southeast and northwest, and offset bedding and cataclastic shears in both normal and thrust motions. At one location, centered on an intense zone of near-vertical, N. $30^{\circ} \mathrm{W}$-trending cataclastic shears, is a near-vertical, N. $30^{\circ} \mathrm{W}$-trending fault that has horizontal mullions and slickenside striations. Riedel and conjugate riedel shears indicate left-lateral motion.

About $1 \mathrm{mi}$ southeast of Lost Hill, along the northern margin of the Benton Hills just east of Sals Creek, there is a possible graben that has dropped Joachim Dolomite and overlying McNairy Sand down between St. Peter Sandstone to the west and Dutchtown Formation to the east. Boundary faults are not exposed and are assigned a very tentative northwest strike.

\section{ENGLISH HILL AREA}

Prompted by reports of possible Quaternary faults in the English Hill area (Stewart, 1942; Stewart and McManamy, 1944), the U.S. Geological Survey (USGS) and the Missouri Department of Natural Resources/ Division of Geology and Land Survey, now known as Missouri Department of Natural Resources, Geological Survey and Resource Assessment Division (MDNR/GSRAD) began a faultexploration research project supported by the Nuclear Regulatory Commission, the USGS National Earthquake Hazards Reduction Program, the USGS National Cooperative Geologic Mapping Program, and the MDNR/GSRAD. Auger drilling by MDNR/GSRAD, acquisition of seismic-reflection profiles (Palmer and others, 1997a,b), and mapping and core drilling (Harrison and others, 1996) preceded fault-exploration trenching. Location of trenches and a generalized geologic map of the English Hill area are shown in figures 3 and 4 . Detailed descriptions of core holes $\mathrm{BH}-1$ and $\mathrm{BH}-2$ are found in Harrison and others (1996).

\section{Trench Descriptions}

Following are descriptions of trenches excavated in the English Hill area during 1995 and 1996. Emphasis is placed on orientations and interpreted kinematics of structural features exposed in the trenches. The term "episodes" is used to group structures into sets that had a similar timing and style of deformation. The term does not correspond to individual fault events or earthquakes. Timing was determined by crosscutting relations or by the youngest unit affected. Style of deformation was interpreted from kinematic analysis of fault-slip data, similar to methods used by Marrett and Allmendinger (1990), and the application of Anderson's (1951) model relating fault geometry and kinematics to controlling stresses. Fault-slip components were measured in the field and include characteristics such as the orientation of fault surfaces, orientation of slip direction determined from slickenside striations, and sense of slip. Assumptions were made that the sampling was representative and that there has been no reorientation of fault-slip components.

Some form of surface or near-surface deformation, mainly faulting, of the unconsolidated Cretaceous and Cenozoic section could be seen in virtually all of the trenches. The rupture characteristics of this unconsolidated material varied greatly, depending on the dominant grain-size fraction of the strata. Faults that cut the more cohesive silts and clays are typically very sharp and well defined. Faults that cut gravels and sands are more diffuse. Many fault surfaces contain gravel and sand grains that have been transported during shearing.

\section{Bollinger Trench}

Figures 5 and 6 are diagrammatic logs of the Bollinger trench, which was excavated on a ridge crest in the southwestern part of the English Hill area (fig. 3). This trench exposed two complex fault systems (a "deeper" and an "upper"), both of which contain highangle and subhorizontal surfaces. Although crosscutting relations were not observed, kinematic interpretations and relations of the faults to the modern soil profile suggest that the two systems formed under different stress regimes at different times.

The deeper system consists of a high-angle fault $(A)$ and several subhorizontal faults that steepen and merge into a single high-angle fault $(B)$ to the southeast. Fault $A$ strikes N. $15^{\circ}$ E., dips $45^{\circ}-80^{\circ}$ $\mathrm{SE}$., and cuts the unnamed Eocene unit (Tu) and McNairy Sand $(\mathrm{Km})$. Neither slickenside striations nor mullions were observed on fault $A$, but deformed fragments of bedded McNairy Sand caught up in the fault indicate oblique, reverse motion. The upward extent of fault $A$ could not be traced into the modern $B$ soil horizon.

The subhorizontal faults are sharp, well-defined structures that have northeasterly strikes and northwest-southeast-trending striations. Fault $A$ shows intertwined relations with the subhorizontal faults; in places it merges with them, in other places it is truncated by them, and at one location, fault $A$ truncates a subhorizontal structure. These relations are interpreted to indicate a common origin for fault $A$ and the subhorizontal faults.

A consistent 8- to 12-in-thick, subhorizontal-fault-bounded interval of strongly deformed McNairy strata occurs below the unnamed Eocene unit and above relatively undeformed McNairy strata. Asymmetrical folds (not shown on fig. 5 and 6) within this deformed interval indicate that the hanging wall of fault $A$ moved 
toward S. $20^{\circ} \mathrm{W}$. to $\mathrm{S} .50^{\circ} \mathrm{W}$. This suggests an oblique, reverse motion on fault $A$ and is consistent with the kinematics under a northeast-oriented maximum horizontal stress (fig. 7A).

To the southeast, the subhorizontal structures merge and steepen into fault $B$ that strikes $\mathrm{N}$. $60^{\circ} \mathrm{W}$. and dips approximately $52^{\circ} \mathrm{NE}$., and is marked by $15^{\circ}-20^{\circ}$ NW.-raking slickenside striations and mullions. Kinematic indicators along fault $B$ are consistent with the movement indicated on the subhorizontal faults. Antithetic shears to fault $B$ strike N. $65^{\circ} \mathrm{E}$. and $\operatorname{dip} 42^{\circ} \mathrm{SE}$.; slickenside striations rake $0^{\circ}-19^{\circ} \mathrm{NE}$. This deeper fault system may represent a rollover, or flower structure, along a northwest-trending, left-lateral, strike-slip fault zone. The age of faulting is constrained only as postEocene.

The upper fault system consists of strike-slip fault $C$ that strikes N. $13^{\circ}-30^{\circ} \mathrm{E}$. and dips $80^{\circ}-84^{\circ} \mathrm{SE}$.; slickenside striations rake $0^{\circ}$. This fault flattens and rotates at depth, striking N. $42^{\circ} \mathrm{W}$. and dipping $35^{\circ} \mathrm{NE}$; s slickenside striations rake $80^{\circ} \mathrm{NW}$. Both Wilcox Group (Tw) and Quaternary colluvial material ( $\mathrm{Oc} 2$ ) have been dragged along the fault surface. Slip directions suggest a northnortheast extensional motion (fig. 7B).

The upper fault system juxtaposes Wilcox Group sands and clays, and Quaternary colluvial material against the unnamed Eocene unit. Much of the Wilcox is brecciated and contorted (Twb unit). The Quaternary colluvium (Oc2) consists dominantly of silt (reworked loess) and lesser sand and gravel concentrated at the base. Quaternary material $\left(\mathrm{Oc}_{\mathrm{c}}\right)$ exposed in the hanging wall of the upper fault system bears no resemblance to Quaternary deposits in the footwall, which consist of Sangamon Geosol (Qsg) developed on silty colluvium (reworked loess) and alluvial sand overlain by gravel- and sand-rich colluvium (Oc1) (fig. 5). These footwall Quaternary deposits were laid down in a paleochannel (trending S. $50^{\circ} \mathrm{W}$., plunging $10^{\circ} \mathrm{SW}$.). The absence of Wilcox Group in the footwall attests to erosion prior to Sangamon time. Because fault $C$ offsets the modern $\mathrm{B}$ soil horizon and fault $A$ cannot be traced into the $\mathrm{B}$ soil horizon, the upper fault system is interpreted to be younger than the deeper fault system.

\section{Old Quarry Trench}

The Old Quarry trench (fig. 8) was excavated approximately 800 $\mathrm{ft}$ north-northeast of the Bollinger trench along the eastern margin of an abandoned quarry immediately south of the English Hill Road (Scott County Road 329) at approximately mid-hill elevation (fig. 3). Several high-angle normal faults were revealed in the trench. The faults cut Mounds Gravel and a well-defined Quaternary sequence of Sangamon Geosol (developed on Loveland Loess), Roxana Silt, and Peoria Loess. Thermoluminescence ages (table 1) confirm the field identification of Peoria Loess and Roxana Silt, and establish a maximum age of faulting in this trench of 21.9 $\pm 3.3 \mathrm{ka}$. Colluvial material caps the stratigraphic sequence and truncates all faults. A horizon at the base of the colluvium contained several fragments of leaves, twigs, and nuts, four of which yielded modern ( $<150$ yr) ${ }^{14} \mathrm{C}$ ages (Harrison and others, 1997).

The major fault exposed in the trench is called the English Hill fault because it is believed to be the same structure described and named by Stewart (1942). This fault juxtaposes Peoria Loess in the hanging wall against Mounds Gravel in the footwall and consists of several braided strands that strike N. $35^{\circ} \mathrm{E}$. and dip $88^{\circ} \mathrm{SE}$. Slickenside striations rake $90^{\circ}$. Fault-bounded slivers of Roxana Silt; gouge-like, sandy clay material; and many clasts derived from the Mounds Gravel occur along fault surfaces. Shallow holes dug in the floor of the trench in the hanging wall of the English Hill fault encountered Roxana Silt just below trench-floor level, indicating approximately $15 \mathrm{ft}$ of throw on the structure.

To the northwest in the footwall of the English Hill fault, three antithetic faults and one synthetic fault form a horst-and-graben sequence. Away from the master fault, attitudes and rakes determined from slickenside striations on these faults are (1) strike $\mathrm{N}$. $15^{\circ} \mathrm{E}$., dip $78^{\circ} \mathrm{NW}$; rake $69^{\circ} \mathrm{NE}$.; (2) strike N. $35^{\circ} \mathrm{E}$., dip $71^{\circ}$ NW.; rake $90^{\circ}$; (3) strike E.-W., dip $74^{\circ}$ S.; and (4) strike N. $43^{\circ}$ E., $\operatorname{dip} 65^{\circ} \mathrm{NW}$. Stratigraphic separation on the first three of these faults ranges from 1 to $4 \mathrm{ft}$; because of lack of sufficient trench depth, no offset contacts were seen on the northwesternmost fault. A small N. $35^{\circ}$ E.-trending fold was observed near the center of the graben.

Kinematic indicators provided by slickenside striation data on these larger faults exposed in the Old Quarry trench (fig. 9) suggest overall northwest-southeast extension. A seismic-reflection profile acquired along the trench (Palmer and others, 1997b) shows that the English Hill fault is nearly vertical to depths of at least $200 \mathrm{ft}$ and the contact between Cretaceous and Paleozoic rocks is offset across the fault.

Several minor fractures, having small normal displacements of a few inches to fractions of an inch, occur in the Mounds Gravel in the footwall of the English Hill fault. Attitudes vary in both strike and dip (fig. 10). There are several minor fractures in the Sangamon Geosol (fig. 11) that cannot be traced into overlying or underlying units. With one exception, the fractures do not indicate discernible displacement. That exception had striations indicating left-lateral, normal oblique slip on a N. $63^{\circ} \mathrm{W}$.-striking fracture that is consistent with overall northwest-southeast extension.

Many vertical or near-vertical fractures having no discernible displacement were observed in the Peoria Loess, particularly in the hanging wall of the English Hill fault. Although fractures in unfaulted loess are common, the density of fractures in the hanging wall of the English Hill fault is at least three times that observed in the footwall, suggesting a tectonic origin. A comparison between hanging-wall versus footwall fractures in the Peoria Loess (fig. 12) indicates an overall polygonal pattern, but the hanging wall contains a much greater concentration of northwest-southeast-trending fractures. All hanging-wall fractures are truncated by the English Hill fault.

A notable difference in soil profile thickness was observed across the English Hill fault. In the footwall, modern soil developed on the Peoria Loess has been welded to the buried Farmdale soil, which developed on Roxana Silt. The resulting soil profile extends from the surface down to the Sangamon Geosol. In the hanging wall, however, modern soil development is restricted to the uppermost 1 to $3 \mathrm{ft}$. The footwall soil profile is anomalously thick for the area, probably indicating development in a depression or graben that had experienced relatively high rates of water influx. This condition suggests the possibility of two episodes of faulting. The graben structure in the footwall formed first and then was followed by deformation along the English Hill fault, which downdropped the hanging wall.

\section{Uncle John Trench}

The Uncle John trench (fig. 13) was excavated across a northeast-trending valley in the northwestern part of the English Hill area (fig. 3). This valley was chosen for fault exploration because it is relatively steep sided and deep, and yet has very little surface drainage area. Furthermore, this valley and another similar-trending valley to the southwest form a conspicuous $\mathrm{N} .55^{\circ} \mathrm{E}$. photo-linear feature, 
parallel to one of the dominant structural trends in the Benton Hills.

The trench exposed the Uncle John fault that strikes $\mathrm{N} .25^{\circ} \mathrm{W}$. and dips $50^{\circ} \mathrm{NE}$. near the center of the valley. In addition, the trench exposed a series of $\mathrm{N}$. $70^{\circ} \mathrm{W}$.-striking, NE.-dipping listric faults in the footwall of the Uncle John fault, and several $\mathrm{N} .70^{\circ}$ W., steeply NE.-dipping slip surfaces in the hanging wall. Many slickenside striations and scallop-shaped structures on the listric faults indicate that their hanging walls moved towards $\mathrm{N} .30^{\circ} \mathrm{W}$. (fig. 14A). Subhorizontal striations and mullions on the Uncle John fault indicate a strong component of shear along its strike, consistent with movement on the listric faults (fig. 14A). Slip surfaces in the hanging wall contain many mullions and striations that rake $90^{\circ}$, suggesting another episode of faulting that had a northeastsouthwest extensional direction (fig. 14B).

Stratigraphic and crosscutting relations further indicate two episodes of movement on faults exposed in the Uncle John trench: (1) Normal or transtensional displacement occurred on the Uncle John fault which placed Wilcox Group adjacent to Porters Creek Clay. Both of these units have soils interpreted to be the Sangamon Geosol, suggesting that the oldest faulting is pre-Sangamon. Displacement was probably on the order of tens of feet. (2) Listric faults exposed in the footwall of the Uncle John fault indicate a few feet of down-to-the-northwest extension that reactivated the Uncle John fault as a transtensional strike-slip structure. This youngest faulting offset the base of the Peoria Loess; but because of extensive soil development throughout the Peoria, it was impossible to determine if its entire thickness was faulted. Also offset by this youngest faulting is the thin unnamed Quaternary gravel $(\mathrm{Og} 3)$ deposit that consists of reworked Mounds Gravel and a Quaternary colluvial-alluvial deposit that consists of gravel (less than 2 in. in diameter) supported by a matrix of sand and silt. It is uncertain as to whether this latter unit is an old channel fill or a fault-related colluvial wedge, which would indicate another event of faulting.

The Uncle John trench is within a valley blanketed by a consistent thickness of Peoria Loess. The loess does not thicken along the valley axis suggesting that it sagged or was downwarped after Peoria Loess deposition. This evidence is further supported by the thin Quaternary gravel $(\mathrm{Og} 3)$, which also is not thickened or incised along the valley axis. The valley is interpreted to be a synform created by northeast-trending en echelon transtensional structures. A Mini-Sosie seismic-reflection profile traversed an extension of this valley approximately $1,800 \mathrm{ft}$ to the northeast, and a well-defined graben structure that cuts the contact between Paleozoic and Cretaceous rocks was imaged (Palmer and others, 1997a). A synform that warped the contact between Paleozoic and Cretaceous rocks was imaged (Palmer and others, 1997b) by a shotgun seismic-reflection profile that crossed the valley approximately $500 \mathrm{ft}$ to the northeast of the Uncle John trench.

\section{Powerline Trench}

The Powerline trench was excavated approximately $300 \mathrm{ft}$ east of the Uncle John trench and $200 \mathrm{ft}$ north of the Old Quarry trench (fig. 3). The trench was dug in a N. $70^{\circ} \mathrm{W}$.-trending direction and encountered a northeast-striking normal fault at an acute angle; therefore a short perpendicular cutout was dug to better expose the structure (fig. 15).

This oblique-slip, normal fault strikes N. $78^{\circ} \mathrm{E}$. and dips $64^{\circ} \mathrm{SE}$. It juxtaposed Peoria Loess in the hanging wall against Mounds Gravel in the footwall. Stratigraphic separation is a minimum of 8 $\mathrm{ft}$. Bedding in the Mounds Gravel strikes N. $55^{\circ} \mathrm{W}$, oblique to the fault, dips $5^{\circ}-15^{\circ} \mathrm{SW}$., and steepens adjacent to the fault with a sense of normal drag. The fault zone has a well-defined surface that is marked by mullions and slickenside striations that rake $75^{\circ}-80^{\circ}$ NE. A 3- to 4-in-wide zone of shearing in the footwall contains pebbles aligned parallel to the fault. Isolated pebbles extend 1 to 2 in. into the hanging-wall loess. A pinkish discoloration in the loess adjacent to the fault could be a sliver of Roxana Silt or could have resulted from oxidation by ground-water flow.

Loess in the hanging wall in proximity to the fault contains many northwest-dipping fractures that rapidly diminish beyond $2.5 \mathrm{ft}$. The orientation of the fractures and the rake direction of striations on the fault indicate northwest-southeast extension (fig. 16). The northwest-dipping fractures immediately adjacent to the fault are interpreted as riedel shears.

Many N. $60^{\circ}-70^{\circ}$ W.-striking, near-vertical fractures containing silt and iron-manganese-oxide encrustations were found in the southeastern half of the Powerline trench (fig. 15). These occur in proximity to where a traceable bed of Roxana is terminated abruptly (fig. 15). However, no definable fault surface or any other features could be discerned.

\section{Hillcrest Trench}

The Hillcrest trench was dug approximately $200 \mathrm{ft}$ east of the Powerline trench (fig. 3). The trench exposed one normal fault that offset Peoria Loess (probably reworked and in part colluvial), unnamed Quaternary gravel 3, and Wilcox Group (fig. 17). High on the southwestern wall of the trench, the fault has an E-W strike, a $57^{\circ} \mathrm{S}$. dip, and a rake of $60^{\circ} \mathrm{E}$.; low on the wall, it changes to a $\mathrm{N} .85^{\circ} \mathrm{W}$. strike, $84^{\circ} \mathrm{SW}$. dip, and rakes $75^{\circ} \mathrm{SE}$. In the floor of the trench, the fault strike doglegs sharply to N. $45^{\circ}$ E., and its dip flattens to $60^{\circ} \mathrm{SE}$; slickenside striations rake $90^{\circ}$ (fig. 18).

Stratigraphic offset of the Quaternary gravel-Peoria Loess contact is approximately $3 \mathrm{ft}$, and stratigraphic offset on the WilcoxQuaternary gravel contact is approximately $8 \mathrm{ft}$. This increase in stratigraphic offset suggests two episodes of faulting: an older episode that occurred after deposition of the unnamed Quaternary gravel 3 and prior to or during deposition of Peoria Loess, and a younger post-Peoria episode. It is important to note the differences between the stratigraphic section exposed in the Hillcrest trench and that exposed in the Powerline trench only $200 \mathrm{ft}$ away. Mounds Gravel, Sangamon Geosol, and Roxana Silt are absent from the Hillcrest trench section, and their position is occupied by the Quaternary gravel deposit, which consists of reworked Mounds clasts in a silty and sandy matrix. This omission of strata is interpreted to represent local uplift, erosion, and redeposition in post-Roxana-pre-Peoria time or during early Peoria deposition.

\section{Upper Rainbow Trench}

The Upper Rainbow trench was excavated along the flank of a northerly trending ridge approximately $150 \mathrm{ft}$ east of the Hillcrest trench (fig. 3). Some of the most complex structures encountered in the English Hill area were observed in this trench (fig. 19). This trench also revealed the most complete record of deformation at English Hill. From crosscutting faults and stratigraphic relations, several episodes of faulting were recognized that include normal, strike-slip, and thrust faults. Reactivation of some faults is strongly suggested. A seismic-reflection profile acquired parallel to the Upper Rainbow trench (Palmer and others, 1997b) shows several high-angle faults, both normal and reverse, in the subsurface that 
have offset the contact between Cretaceous and Paleozoic strata.

For clarity of description, deformation effects that are similar in timing and style are considered to be an episode and numbered sequentially from oldest to youngest. As discussed below, episodes 6 and 7 probably form a continuum, or are correlative.

Episode 1 (UR-1). - The oldest faults observed in the Upper Rainbow trench are Cretaceous in age. They consist of conjugate sets of normal faults found only in the McNairy Sand. Most strike east-west and have offsets of a few in. or less. Because they are too small to show at this scale, these faults are not depicted on figure 19. Similar microfaults in Cretaceous beds have been observed at many other locations in the Benton Hills and in southern Illinois (Harrison and others, 1996; Nelson and Harrison, 1993).

Episode 2 (UR-2).-An early Tertiary (Paleocene or Eocene) unconformity, expressed as Wilcox Group resting directly upon Cretaceous McNairy Sand at various locations in this trench, indicates local uplift and erosion. Porters Creek Clay, which should occur between these two units, is $36.7 \mathrm{ft}$ thick in drill hole $\mathrm{BH}-1$ (see fig. 3 for location) approximately $400 \mathrm{ft}$ to the west. The localization of this unconformity is further demonstrated by exposures in the hanging wall and footwall of fault $P$ where Wilcox Group rests unconformably upon McNairy Sand. The unconformity is marked by an iron-cemented bed of gravel and sand. In the footwall of fault $P$, approximately $4 \mathrm{ft}$ of Clayton Formation rests upon McNairy Sand (determined from augering, as the contact is below the trench floor in fig. 19). Clayton Formation is absent in the hanging wall. Another expression of this unconformity occurs between faults $D$ and $E$, where beds of the McNairy Sand strike N. $20^{\circ} \mathrm{E}$. and dip $49^{\circ} \mathrm{SE}$., and are overlain by subhorizontal beds of the Wilcox Group.

Episode 3 (UR-3).-Normal faulting of post-Mounds and preunnamed Quaternary gravel 3 age is indicated by faults $D$ and $E$. Fault $D$ strikes N. $50^{\circ} \mathrm{W}$. and dips $70^{\circ} \mathrm{NE}$., cuts only beds of the McNairy Sand and Wilcox Group, and is truncated by the Quaternary gravel. The clay-sand contact within the Wilcox Group is offset less than $1 \mathrm{ft}$, yet the contact in the footwall dips steeply $\left(\sim 60^{\circ}\right)$ towards fault $D$. Fault $E$ strikes N. $50^{\circ} \mathrm{E}$., dips $78^{\circ} \mathrm{SE}$., and shows stratigraphic separation on the Wilcox-Quaternary gravel 3 contact of approximately $4 \mathrm{ft}$. The Wilcox Group increases in thickness from approximately $4 \mathrm{ft}$ in the footwall to approximately $22 \mathrm{ft}$ in the hanging wall, indicating post-Wilcox faulting and erosion prior to Quaternary gravel 3 deposition. The fact that Quaternary gravel 3 was preserved on the erosional surface rather than Mounds Gravel indicates that the fault is most likely post-Mounds in age.

No kinematic indicators were found on either faults $D$ or $E$, so they are assumed to be normal faults. If so, they can be interpreted as a conjugate set that formed under east-west extension (fig. 21). Other faults, exposed down trench to the southeast such as $J, K$, $Q, Z, A A, A B, A C, A D$, and $A E$, also could have been active during this period of faulting, but this is uncertain.

Episode $4(U R-4)$.- - Faulting contemporaneous with deposition of the unnamed Quaternary gravel 3 deposit is indicated by fault $F$ that offsets the lower contact of this gravel with the Wilcox Group, but not the upper contact of the gravel with Peoria Loess. Fault $F$ strikes N. $50^{\circ} \mathrm{E}$. and dips $78^{\circ} \mathrm{NW}$. In the floor of the trench, fault $F$ is truncated by fault $G$. No kinematic indicators were found on fault $F$. Fault $Q$ also might have been active during deposition of the Quaternary gravel 3, because this gravel is approximately $8 \mathrm{ft}$ thick in the hanging wall, and at most $2 \mathrm{ft}$ thick in the footwall.

Episode 5 (UR-5).-Faults $H, I(?), N, O, S, T, V$, and $X$ are thrusts. All of these structures dip at low angles, except for $S$ which dips at $55^{\circ}$; and, except for fault $I$, all have placed older units over younger. The youngest unit displaced by thrust faults in this trench is the Wilcox Group; however as discussed later, Sangamon Geosol is involved in thrusting in the Lower Fence Line trench, the unnamed Quaternary gravel 1 is involved in the Seismic Line trench, and Roxana Silt is cut by strike-slip faults believed to be part of this episode in the Tuesday trench. At some places in the Upper Rainbow trench, normal faults of episodes 3 and 4 have been truncated by thrusts.

In the footwall of fault $O$, S-folds in the McNairy Sand and drag on the unconformity between the McNairy Sand and Wilcox Group indicate top-towards-S. $35^{\circ} \mathrm{E}$. movement, which is consistent with slickenside striations observed on the thrust faults (fig. 22).

Episode 6 (UR-6).-Deformation along faults $E, G$, and $Q$ define a sixth episode of normal faulting that involves Peoria Loess. The field identification of Peoria Loess is confirmed by a thermoluminescence age of $17.0 \pm 2.7 \mathrm{ka}$ (table 1) of a sample from near the base of this unit in the hanging wall of fault $Q$ (sample 5 on fig. 19). This age is also a conservative maximum age constraint for this faulting episode. Near the northwestern, uphill end of the Upper Rainbow trench, faults $E$ and $G$ bound a nearly symmetrical graben that has dropped the Peoria Loess approximately $4 \mathrm{ft}$. Near the center of the trench, fault $Q$ is the master fault for an asymmetrical half graben which has dropped Peoria Loess approximately 50 to $60 \mathrm{ft}$. Fault $Q$ can be traced to the present-day land surface where a 2.5- to 3-ft-high scarp, or break in slope, occurs. Kinematic indicators provided by slickenside striations and sense of displacement indicate that this episode of faulting was the result of northwest-southeast extension (fig. 23).

Faults $A E$ and $A F$ at the southeastern end of the trench also are thought to have formed during episode 6 . Fault $A E$ zigzags along strike from $\mathrm{N} .80^{\circ} \mathrm{E}$. to $\mathrm{N} .80^{\circ} \mathrm{W}$., dips to the south from $29^{\circ}$ to $60^{\circ}$, and is marked by slickenside striations that indicate a $90^{\circ}$ rake. Quaternary colluvium (Oc) drapes over this fault forming a small 1-ft-high scarp on the present-day land surface. A 2- to 4-inthick zone of fine- to medium-grained quartz sand, rimmed by clay film, and mica occurs along the fault surface. Fault $A F$ strikes $\mathrm{N}$. $75^{\circ} \mathrm{W}$., dips $57^{\circ} \mathrm{NE}$., and is antithetic to and truncated by fault $A E$.

Along the trench profile these two faults form a V-shaped graben that contains unsorted colluvial material (micaceous silt, loess-like silt, fine- to medium-grained quartz and glauconitic sand, pebbles, and cobbles as much as 2 in. in diameter) derived from the other Cretaceous and Cenozoic units exposed in the trench. The colluvial material is approximately 6 to $7 \mathrm{ft}$ thick. There is a gross stratigraphy in the colluvial material defined by abundant glauconite in the lowermost $2 \mathrm{ft}$ that is virtually absent in the upper 4 to $5 \mathrm{ft}$. In addition, gravel clasts are sparse in the lowermost 2 to $3 \mathrm{ft}$ and become more abundant upward. Slickensided fracture surfaces are very abundant throughout the colluvial material.

Additional trenching approximately $17 \mathrm{ft}$ into the hillside provided additional exposures of the colluvial-wedge deposit. This deposit was laid down against a scarp along fault $A E$. Adjacent to the fault, the deposit consists of about $8 \mathrm{ft}$ of dominantly gravel, sand, and minor silt. It fines outward, away from the fault, to sand and silt. Fault $A F$ on figure 19 juxtaposes the coarse-grained, proximal material against the fine-grained, distal material.

Charcoal is commonly found throughout the colluvial material. Radiometric ${ }^{14} \mathrm{C}$ age dates of eight pieces of this charcoal are strongly bimodal: $4,980 \pm 60 \mathrm{yr}, 4,920 \pm 60 \mathrm{yr}, 4,780 \pm 50 \mathrm{yr}$, and $4,740 \pm 50 \mathrm{yr} ; 1,310 \pm 60 \mathrm{yr}, 1,240 \pm 50 \mathrm{yr}, 1,220 \pm 50 \mathrm{yr}$, and $1,210 \pm 50 \mathrm{yr}$. Within the graben, these two groups are segre- 
gated by an obscure, near-vertical boundary, such that the older $(4,980-4,740)$ charcoal pieces are found downhill from the younger $(1,310-1,210)$ pieces. A thermoluminescence age of 18.4 \pm 2.2 ka was obtained from the lower third of the colluvial material (sample 6 on fig. 19, see table 1). This age indicates that most of the silt in the colluvial material was derived from Peoria Loess and was rapidly deposited, such that it was not re-exposed to sunlight long enough to reset the luminescence signal.

Episode 7 (UR-7).-The seventh episode of faulting is defined by strike-slip motion on faults $L, M$, and $U$. Faults $L$ and $M$ have northeasterly strikes, steep dips, and merge upward (figs. 19 and 20). Mullions and striations on both faults indicate subhorizontal movement. Fault $U$ is a vertical structure that strikes N. $35^{\circ} \mathrm{E}$. and branches upward into a network of dipping faults, forming a flower structure typical of strike-slip deformation. Mullions and striations on the vertical segment and the branches indicate subhorizontal movement.

Crosscutting relations between strike-slip fault $M$ and thrust faults $N$ and $O$, and strike-slip fault $U$ and thrust fault $T$ in this trench indicate that strike-slip faults are younger than the thrust faults (episode 5). In the Seismic Line and Tuesday trenches, Peoria Loess is cut by strike-slip faults thought to also be part of episode 7 deformation, indicating a probable Holocene age. The relative ages of episodes 6 and 7 are not straightforward and they could have formed concurrently as discussed below.

Scallop-shaped structures on fault surfaces and the vergence direction of subsidiary shears indicate right-lateral displacement in a northeast-southwest-oriented maximum horizontal stress direction (fig. 24). Piercing points are lacking; therefore, the precise amount of displacement is unknown. However, the mismatch of stratigraphy across fault $U$ suggests at least several tens of feet of displacement.

Discussion and interpretation of episodes 6 and 7.- It is interpreted that the normal faulting of episode 6 and the strike-slip faulting of episode 7 are probably contemporaneous. The basis for this interpretation is twofold. (1) They had similar stress orientations (figs. 23 and 24) indicating that the styles and orientations of faulting are compatible. (2) Structural features related to faults $Q$ and $U$ are best explained if the faults are considered to be coeval. Tertiary and Quaternary beds in the hanging wall of fault $Q$ have been rotated to dips of about $30^{\circ}$, but only as far as fault $U$, where they abruptly flatten to subhorizontal. The contact between Cretaceous and Tertiary rocks immediately southeast of fault $U$ on figure 20 has not been rotated as much as the contacts between faults $Q$ and $U$. Furthermore, the contacts between units in the hanging wall of fault $Q$ strike N. $60^{\circ}-70^{\circ} \mathrm{E}$., at an acute angle to the N. $42^{\circ} \mathrm{E}$.striking fault $Q$. This is inconsistent with what one would expect in the hanging wall of a listric normal fault, where bedding attitudes should be parallel to fault strike. The implied clockwise rotation is consistent with right-lateral, strike-slip motion on fault $U$.

A proposed model for linking coeval strike-slip movement on faults $L, M$, and $U$ to normal movement on fault $Q$ is illustrated in figure 20. In this model, fault $Q$ is interpreted to be a transtensional structure that developed in an area of extension between strike-slip faults $L-M$ and $U$. In addition, it is impossible to balance the cross section in figure 20 without allowing for strike-slip motion.

The presence of colluvial material in the graben bound by faults $A E$ and $A F$ is highly significant. This is the only material in all of the English Hill trench sites that has the potential to date individual surface-rupturing events. The ages of charcoal contained within this deposit provide maximum constraints on two recent fault events: one that occurred just after $4,980-4,740{ }^{14} \mathrm{C}$ years $\mathrm{BP}(2 \sigma$ calibrated calendar ages of $\mathrm{BC} 3,747$ to 3,369$)$ and one just after $1,310-1,210{ }^{14} \mathrm{C}$ years BP $(2 \sigma$ calibrated calendar ages of $\mathrm{AD}$ 968 to 639$)$.

Episode 8 (UR-8). - The fact that the colluvial wedge deposit containing charcoal is itself faulted indicates the occurrence of yet another fault episode, the most recent identified at the English Hill site. Movement along fault $A F$ is interpreted to have occurred during this episode. No kinematic indicators were found on fault $A F$, so it is assumed that this $\mathrm{N}$. $75^{\circ} \mathrm{W}$., $57^{\circ} \mathrm{NE}$.-dipping structure formed during north-northeast to south-southwest extension. Similarly oriented faults exposed in the Bollinger, Old Quarry, and Uncle John trenches possibly formed during this episode.

\section{Lower Fence Line Trench}

The Lower Fence Line trench was excavated approximately 150 $\mathrm{ft}$ east of the upper end of the Upper Rainbow trench (fig. 3). The trench exposed a single thrust fault striking $\mathrm{N}$. $35^{\circ} \mathrm{E}$., dipping $10^{\circ}-40^{\circ} \mathrm{NW}$. (fig. 25), and on strike with thrust faults $\mathrm{N}, \mathrm{O}$, and $T$ in the Upper Rainbow trench. The fault surface is poorly defined, and no striations or mullions were observed. Beds of the Porters Creek Clay, striking N. $25^{\circ} \mathrm{W}$. and dipping $20^{\circ} \mathrm{NE}$., were thrust over the unnamed Quaternary gravel 1 deposit (Og1), which consists of colluvial silt, sand, and gravel deposits in a red clay matrix that has been modified by the Sangamon Geosol. Recent surface colluvial material is unfaulted.

The occurrence of Porters Creek Clay is significant because it helps define limits to the area where this unit is absent, presumably from pre-Wilcox, Eocene uplift and erosion. Figure 26 shows the known area where Porters Creek is absent. This area could have extended farther to the southwest.

\section{Upper Fence Line Trench}

The Upper Fence Line trench was excavated about $13 \mathrm{ft}$ uphill from the Lower Fence Line trench (fig. 3). No faults were found in this trench (fig. 27); however, closely spaced N. $55^{\circ}-60^{\circ}$ E.-striking fractures have cut Roxana Silt and Peoria Loess.

Several stratigraphic relations and the attitudes of contacts in this trench imply structural deformation: (1) The absence of Mounds Gravel helps delineate the area of its erosion (fig. 28). This absence is interpreted to have resulted from localized uplift prior to deposition of Roxana Silt. (2) Comparison of the stratigraphic position of the unnamed Quaternary gravel $2(\mathrm{Og} 2)$ exposed in this trench with that of the unnamed Quaternary gravel 1 (Og1) deposit exposed in the nearby Lower Fence Line trench suggests that they are different units. The unnamed Quaternary gravel 2 unit is interpreted as thus because it underlies Roxana Silt. Uplift and erosion during post-Sangamon and pre-Quaternary gravel 2 time is indicated. This was possibly the same erosional event that removed the Mounds Gravel. (3) The Sangamon Geosol is absent in this trench, but is well developed only $10 \mathrm{ft}$ away in shallow excavation pits. From the trench profiles presented in this report, unpublished auger data accumulated by the Missouri Department of Natural Resources, Geological Survey and Resource Assessment Division, and surface mapping, the extent of Sangamon Geosol removal can be fairly accurately determined (fig. 29). (4) The contact between the unnamed Quaternary gravel 2 and Roxana Silt and Peoria Loess strikes $\mathrm{N} .40^{\circ} \mathrm{W}$. and dips $25^{\circ} \mathrm{NE}$. This dip suggests structural rotation during post-Peoria time. 


\section{Seismic Line Trench}

The Seismic Line trench was excavated approximately $350 \mathrm{ft}$ southeast of the Fence Line trenches (fig. 3). An illustration of the northwestern wall of this trench is shown in figure 30. As in the Upper Rainbow trench, several episodes of complex faulting were found.

The oldest faults are thrusts that strike northeast and dip to the southeast. These faults cut the McNairy Sand in the southwestern part of the trench. Asymmetrical folds and slickenside striations indicate dip-slip motion towards the southeast (fig. 31). Because of similar orientations and proximity, these thrust faults in the Seismic Line trench are interpreted as correlative to episode 5 faults in the Upper Rainbow trench.

Several faults were recognized in the Seismic Line trench that are younger than the thrust faults. These younger faults have complex relations. They include normal faults; a northeast-striking, right-lateral, strike-slip fault; and riedel shears $(\mathrm{R})$, conjugate riedel shears $\left(\mathrm{R}^{\prime}\right)$, and antithetic $\mathrm{P}$ shears related to the right-lateral, strike-slip fault.

Faults $A L$ (actually two faults), $A O, A P$, and $A Q$ are normal faults. Kinematic indicators provided by fault-surface striations indicate northwest-southeast extension (fig. 32). Normal fault $A Q$ displaces the Roxana-Peoria contact and at several places the normal faults have been truncated by strike-slip faults. It is therefore interpreted, on the basis of similar timing and strain, that the normal faults in this trench are correlative with episode 7 faults observed in the Upper Rainbow trench.

Fault $A M$ is the principal strike-slip fault in this trench. It can best be described as a roll-over structure, in that it is concave downward and steepens with depth, although this is not readily apparent from figure 30 because of the acute angle between the trench and the fault. In the floor of the trench, fault $A M$ strikes N. $55^{\circ} \mathrm{E}$. and dips $85^{\circ} \mathrm{SE}$.; in the wall, the dip flattens to as little as $10^{\circ}$ to the SE. Slickenside striations and steps along fault $A M$ indicate right-lateral motion. Fault $A M$ truncates normal faults $A O$ and $A P$, and offsets units as young as Sangamon Geosol.

Several structures observed in the Seismic Line trench are interpreted to be antithetic conjugate riedel ( $\left.\mathrm{R}^{\prime}\right)$ shears, synthetic riedel (R) shears, and antithetic $\mathrm{P}$ shears that formed in conjunction with right-lateral slip along fault $A M$. Northwest-striking faults $A R$ and $A S$, both of which are marked by horizontal or subhorizontal slickenside surfaces and cut Sangamon Geosol (in floor of trench), Roxana Silt, and Peoria Loess, are interpreted as left-lateral $\mathrm{R}^{\prime}$ shears. There has been approximately $2 \mathrm{ft}$ and $1.5 \mathrm{ft}$ of left-lateral displacement of mottled, polygonal patterns in the Sangamon Geosol by faults $A R$ and $A S$, respectively. The northwest-striking fractures mapped in the eastern part of the trench (fig. 30) are also probably $\mathrm{R}^{\prime}$ shears, although no striations or offsets were observed.

The west-northwest-striking fault $A G$ (fig. 30 ) is interpreted as a synthetic $\mathrm{R}$ shear to fault $A M$. Fault $A G$ has subhorizontal slickenside striations, displays a concave downward or roll-over characteristic, and truncates older normal faults. The northerly striking fault $A N$ is interpreted to be an antithetic $\mathrm{P}$ shear to fault $A M$. Fault $A N$ has slickenside striations that rake $10^{\circ} \mathrm{SW}$. and side-wall rip outs indicating a left-lateral motion.

Figure 34 diagrammatically illustrates the strike-slip fault data described above. A riedel model of right simple shear for these data indicates a west-northwest-east-southeast maximum-horizontalstress direction for this faulting (fig. 34). The relatively high $\phi / 2$ angle (angle between $\mathrm{R}$ and the principal zone of displacement) is attributed to the unconsolidated nature of the faulted sediments and a resulting low coefficient of friction.

Although complicated by the complex faulting exposed in this trench, it is noteworthy that neither Porters Creek Clay nor Mounds Gravel is present. Their absence suggests that the Eocene and post-Mounds erosional unconformities described earlier extended into this area.

\section{Tuesday Trench}

The Tuesday trench was excavated from the eastern end of the Seismic Line trench at approximately 90 degrees (fig. 3). It revealed the most complex faulting found in the English Hill area (fig. 35). An assortment of strike-slip, normal, and thrust faults was observed. Reactivation of many structures was indicated. Most faults strike north to northeast, although several strike to the northwest (fig. 36). The evaluation of fault episodes in this trench is not straightforward; therefore, interpretation is presented after the description of the better documented major structures.

Fault $A Y$ strikes N-S to N. $5^{\circ} \mathrm{E}$. and has a steep western limb that dips from $45^{\circ}-50^{\circ} \mathrm{W}$., rolling over to subhorizontal to the east. A subhorizontal rake of about $4^{\circ}$ to the north on the steep limb is indicated by slickenside striations and mullions. Carrotshaped scours along the fault surface of the steep limb indicate a left-lateral, strike-slip motion. This is supported by a sinistral vergence direction between the fault and riedel $(\mathrm{R})$ and conjugate riedel $\left(\mathrm{R}^{\prime}\right)$ shears. Along strike to the south, in the wall opposite to that shown in figure 35, fault $A Y$ cuts Peoria Loess. There are many subhorizontal shear surfaces in the Roxana Silt adjacent to this fault. One thermoluminescence age date of $28.0 \pm 2.6 \mathrm{ka}$ from the uppermost Roxana Silt (table 1, see fig. 35 for location) verifies the field identification of this unit.

Fault $A Z$, a left-lateral, strike-slip fault, strikes N. $5^{\circ} \mathrm{E}$. (parallel to fault $A Y$ ), dips $67^{\circ} \mathrm{SE}$, and has a rake of $34^{\circ} \mathrm{NE}$. determined from slickenside striations. This fault separates entirely different Quaternary stratigraphic sequences. Immediately to the south of fault $A Z$, Mounds Gravel is overlain by sandy, gravelly, and silty colluvial deposits ( $\mathrm{Oc} 2$ and Qc1). Farther to the south, Mounds Gravel is absent and is replaced in the stratigraphic section by the unnamed Quaternary gravel $3(\mathrm{Og} 3)$ and coarse-grained silty sand (Os) beneath reworked Peoria Loess and colluvial deposits (Oc1). Sangamon Geosol, Roxana Silt, and most of Peoria Loess are absent. To the north of fault $A Z$, there is a relatively thick Quaternary loess sequence of Sangamon Geosol (developed on Loveland Loess), Roxana Silt, and Peoria Loess. These stratigraphic relations across fault $A Z$ indicate significant localized postRoxana uplift, followed by erosion.

Fault $B M$ strikes N. $35^{\circ} \mathrm{E}$. and dips approximately $40^{\circ} \mathrm{NW}$. A rake of $8^{\circ}$ to the southwest is indicated from slickenside striations and mullions. This fault consists of many braided surfaces that juxtapose McNairy Sand in the hanging wall against the Clayton Formation in the footwall. Fault-bound slivers of both McNairy and Clayton occur along the fault, and in places faulted slivers of Clayton overlie slivers of McNairy. In the hanging wall, McNairy Sand has been cut by a complicated array of branching and curving faults that have both steep and subhorizontal attitudes. The steep faults are generally northwest striking, oblique to fault $B M$. Slickenside striations on the subhorizontal surfaces indicate either northeast or southwest motion, parallel to fault BM. Bedding has been strongly rotated and, despite the complexity of faulting and 
horizontal motion, is always parallel to fault BM (fig. 37).

The upper tip of fault BM has placed McNairy Sand over the Quaternary gravel 3 deposit (fig. 35), but the fault apparently does not cut any higher in the section. This gravel is poorly sorted and consists of chert cobbles derived from the Mounds Gravel, polished black chert and quartz pebbles derived from the Wilcox Group, and iron-cemented conglomerate clasts in a sandy, silty matrix. Many prominent pebble imbrications indicate flow towards the northeast. Multiple movements along fault $B M$ are indicated by the existence of Quaternary gravel 3 directly over McNairy Sand in the hanging wall and directly over Clayton Formation in the footwall. No datable materials were found in any of the Quaternary units overlying fault $B M$.

Discussion and interpretation.-Because of the fault complexity and scarcity of crosscutting relations, it is difficult to decipher different episodes of faulting in the Tuesday trench. From kinematic indicators observed along the faults in this trench and analyses of faults in the other trenches in the English Hill area, at least three episodes of faulting can be interpreted here.

The first episode of faulting is thought to be the result of northwest-southeast compression. Northeast-striking thrust faults (faults $B M$ and $B O$ ) formed and left-lateral, strike-slip motion occurred along faults $A X, A Y$, and $A Z$ (fig. 38). Localized uplift and subsequent erosion removed the Quaternary loess section (Roxana Silt and Peoria Loess) south of fault $A Z$ as discussed above.

The second interpreted fault episode resulted in east-northeast west-southwest extension along faults $A Z, B B, B C, B D, B F, B G$, and $B H$. At some locations, the earlier formed subhorizontal faults are thought to have been reactivated, producing the observed northeast-southwest slickenside striations. At other places, the subhorizontal faults have been offset by this episode of faulting. The graben between faults $A Z$ and $B F$ probably formed during this episode, and the Oc2 deposit may, in part, represent graben fill. Figure 39 is an equal-area stereographic projection of fault data for this interpreted episode.

The final episode of faulting at the Tuesday trench is interpreted as strike-slip motion along fault $B M$. Other faults may have been reactivated, particularly fault $B O$. The principal evidence for this episode is juxtaposition of McNairy Sand above the unnamed Quaternary gravel 3 deposit on fault BM and the fault-bound slivers of Clayton Formation structurally above McNairy Sand along fault $B M$. Slickenside striations on fault $B M$ rake $8^{\circ}$ to the southwest and mark the last motion along the fault. In order to move the hanging wall upward and produce these striations, right-lateral, strike-slip motion is required. The fault-bound slivers of Clayton are interpreted as rip-out structures produced by this strike-slip faulting.

The only other faults exposed in the Tuesday trench that can be readily interpreted as having formed during late strike-slip deformation are faults $A T$ and $A U$ at the extreme northern end of the trench. These faults have the proper orientation to be conjugate riedel ( $\left.\mathrm{R}^{\prime}\right)$ shears, accompanying northeast-trending, right-lateral, strike-slip faulting. These faults are located where an on-strike projection of fault AS exposed in the Seismic Line trench (fig. 30) should cut the Tuesday trench. Figure 40 is an equal-area stereo graphic projection of fault data for this last interpreted episode of faulting.

\section{Weber Trench}

The Weber trench was excavated approximately $500 \mathrm{ft}$ southwest of the southern end of the Tuesday Trench (fig. 3). It is the southeasternmost and topographically lowest trench dug in the English Hill area. A series of horsts and grabens was exposed in the trench (fig. 41). The bounding faults are marked by light-colored silt infilling; no slickenside surfaces were observed.

Stratigraphic relations across the faults suggest two, and possibly three, episodes of faulting. Fault BT juxtaposes Wilcox Group sand and Sangamon Geosol, and both are directly overlain by Peoria Loess. This implies a post-Sangamon and pre-Peoria episode. Roxana Silt is in the hanging wall of fault $B P$, but is absent elsewhere in the trench. This suggests a post-Roxana uplift and subsequent erosion. It is not known if these episodes occurred at the same time or not. The final episode involved Peoria Loess. All faults except BT cut Peoria Loess.

Lacking any kinematic indicators, it is not possible to accurately evaluate stress orientations. However given the fault orientations (fig. 42) and the normal sense of stratigraphic separation across the faults, northwest-southeast extension is suggested.

\section{Correlation of Fault Episodes and Geology of English Hill}

Exposures in the Upper Rainbow trench provide the most complete tectonic record found in the English Hill area and can be used to interpret faulting found in the other trenches (table 2). The oldest episode (UR-1) is expressed by microfaults and normal faults of small displacement confined to the McNairy Sand. Some of the faults in the McNairy Sand exposed in the Tuesday trench (fig. 35) are probably of Cretaceous age, but the complexity of subsequent faulting precludes positive verification. Cretaceous faulting has been documented elsewhere in the Benton Hills (Harrison and Schultz, 1994).

Deformation during the Eocene (UR-2) is suggested by localized, and rather dramatic, unconformities in the Upper Rainbow and Seismic Line trenches (figs. 19, 20, and 30) and in the unique existence of the greater than 20-ft-thick unnamed Eocene unit exposed in the Bollinger trench (figs. 5 and 6). Corehole $\mathrm{BH}-1$ (see fig. 3 for location and Harrison and others (1996) for description) encountered $36.7 \mathrm{ft}$ of Porters Creek Clay, which is absent in the Upper Rainbow trench only $400 \mathrm{ft}$ away. It is interpreted that these phenomena represent localized fault-related uplift and erosion of horst blocks and deposition in a graben.

Although poorly understood, Upper Rainbow episodes 3 and 4 (UR-3 and UR-4) document early Quaternary faulting, possibly the result of east-west and northwest-southeast extension, respectively. These episodes probably are correlative to post-Wilcox Group-preSangamon Geosol faulting observed in the Uncle John trench, post-Sangamon Geosol-pre-Roxana Silt inferred faulting in the Upper Fence Line trench, and post-Sangamon Geosol-pre-Peoria Loess faulting in the Weber trench.

Upper Rainbow episode 5 (UR-5) thrust faulting provides a distinctive northwest-southeast compressional stress signature. Such a stress orientation was not observed in any of the other episodes. Similar deformation was found in the Lower Fence Line, Seismic Line, and Tuesday trenches. Constraints provided in the Lower Fence Line trench indicate that this episode was post-Sangamon Geosol, and in the Tuesday trench is constrained as being post- 
Roxana Silt. Deformation similar in style and timing was observed at other locations in the Thebes Gap area to the east of the Scott City quadrangle (Harrison and others, 1999).

The results of episodes 6 and 7 (UR-6 and UR-7) are the best exposed and most widely expressed deformational features at English Hill. It is probable that these episodes are correlative or form a continuum, such that UR- 6 is a transtensional expression of the same stress field responsible for UR-7 strike-slip faulting. These episodes are post-Peoria Loess and therefore Holocene in age.

The most recent episode (UR-8) is suggested by middle to late Holocene faults that cut the colluvial-wedge deposit at the southeastern end of the Upper Rainbow trench. However, because the relation between this faulting episode and episodes 6 and 7 is unknown, they could all constitute a single episode. Additional evidence for the UR- 8 episode can be found in the northeast-southwest extensional faults that cut the modern $\mathrm{B}$ soil horizon in the Bollinger trench and in similar extensional faults in the Old Quarry and Uncle John trenches. Although more problematic because of the lack of age constraints, the youngest faulting observed in the Seismic Line and Tuesday trenches could also be part of UR-8.

The geologic map of the English Hill area (fig. 4) produced from trench data described in this report, previous trench and auger hole data accumulated by the MDNR/GSRAD, shallow excavations, and surface mapping shows that complex faults formed along dominantly northeast and east-northeast trends that define rhombshaped grabens and horsts. It is interpreted that these faults are the surface expression of basement-controlled strike-slip faults and that step-overs in displacement along the basement faults have at different times produced transtension (pull-apart or rhomb grabens) or transpression (thrust faults) in the overlying Cretaceous-Cenozoic section.

\section{Tectonic Versus Landslide Origin}

There has been much unpublished debate over a landslide versus tectonic origin for structures at English Hill since Stewart's (1942) report that indicated Quaternary faulting existed there. A large part of our evaluation was, therefore, directed toward this controversy. Our preferred interpretation is a tectonic origin. The following is a tabulation of data and arguments supporting or disfavoring each of the possible origins.

Data that possibly support a landslide origin.-

(1) The area is near the New Madrid seismic zone where great historical and prehistorical earthquakes are known to have occurred; earthquakes probably strong enough to have generated large landslides on the scale of observed deformation at English Hill. Small prehistoric landslides have been observed in the Benton Hills (Harrison, 1999).

(2) Most of the observed faults do occur on the southeast-facing slope and crest of English Hill; a site where landslides or slumping could be expected.

(3) Cretaceous and Cenozoic deposits down to a depth of approximately $200 \mathrm{ft}$ are unconsolidated; and therefore, remain susceptible to slumping or landsliding.

(4) The kinematic indicators interpreted for several of the faults exposed in trenches do indicate extension has occurred at English Hill.
Data in support of a tectonic origin.-

(1) Many faults that cut the lithified Paleozoic section, as well as the Cretaceous and Cenozoic sections, have been recognized in the region around English Hill (Harrison and Schultz, 1994; Johnson, 1985; Harrison, 1999). These regional faults have the same trend as structures observed at English Hill and have had a long-lived, episodic history of activity throughout much of the Phanerozoic (Harrison and Schultz, 1994).

(2) Seismic-reflection profiles acquired at English Hill indicate the presence of deep-seated faults in the Paleozoic section beneath the observed surface deformation (Palmer and others, 1997a,b).

(3) Faulting at English Hill has been episodic, occurring in the Late Cretaceous and throughout the Cenozoic. This is not a characteristic of landslides, which become relatively stable after initial movement. Otherwise, the same landslides must have been re-activated throughout the Cenozoic. In addition, the scarp along the southeastern margin of the Benton Hills did not exist until late Tertiary or early Quaternary time, prior to which the site would not have been favorable for landsliding.

(4) Faulting has occurred as much as $1,200 \mathrm{ft}$ back from the slope crest in the Uncle John trench; anomalous for landslides, which typically have break-away scarps along the crest (Varnes, 1978; Jibson and Keefer, 1993).

(5) In the Uncle John trench, extensional motion was towards the northwest, away from the slope. This is consistent with bidirectional tectonic extension, but is in contrast with the unidirectional extension that would have been produced by landsliding to the southeast. Fault motions "into the hill" also were observed at other trench sites, most notably the Bollinger and the Tuesday trenches.

(6) The occurrence of similarly striking normal, thrust, and strikeslip faults in close proximity, and at some places crosscutting each other, is more characteristic of tectonic deformation than landsliding. Whereas all three styles of faulting can occur in landslides, they are segregated with normal faults at the head and sometimes in the body of the slide, thrusts at the toe, and strike-slip faults along the margins; furthermore, the strikes of landslide-derived strike-slip faults should be nearly orthogonal to those of the normal and thrust faults. The complex relations between the three types of faults observed in several of the trenches is more reminiscent of tectonic deformation, particularly deformation occurring in strike-slip regimes (see examples of faulting in the Mecca Hills shown in Sylvester (1988) and Sylvester and Smith (1976)).

(7) The rotation of bedding observed at English Hill is multidirectional, and Cretaceous beds have been rotated more than Cenozoic beds (fig. 43). Rotation during landsliding should be more unidirectional, and both young and old deposits should be rotated equally. On the other hand, tectonic deformation can produce varying bedding attitudes and older deposits that are rotated more than younger deposits if faulting is time-transgressive.

(8) The concave-downward, or roll-over, faults observed in the Seismic Line and Tuesday trenches are characteristic of strike-slip deformation and inconsistent with landslide deformation. Such features have been reported in many strike-slip systems (Naylor and others, 1986; Sylvester and Smith, 1976; Steel and others, 1985; Ramsay and Huber, 1987). In contrast, all faults produced by landsliding are concave upward, flattening out with depth.

(9) The ubiquitous occurrence at English Hill of microstructures on fault surfaces that cannot be gravity driven. 


\section{CONCLUSIONS}

(1) Faults at English Hill are predominantly of a tectonic origin, although some minor slumping cannot be totally ruled out.

(2) Faulting is the surface expression of basement-controlled strike-slip faults imaged on the seismic-reflection profiles.

(3) Faulting has been episodic throughout the Cenozoic and as many as four episodes have occurred during the late Quaternary. Major fault episodes (UR-3 and UR-4) probably occurred in late- to post-Sangamon, pre- to early Roxana time $(\sim 60-50 \mathrm{ka})$ and again (UR-5) in syn- or post-Roxana, pre-Peoria time ( 35-25 ka). This latter episode is unique and enigmatic in that it appears to be the result of northwest-southeast horizontal compression, at nearly right angles to all other interpreted neotectonic stresses and the present-day regional stress field of east-northeast, subhorizontal compression determined by Zoback and Zoback $(1980,1989)$ and Zoback (1992). At least two episodes of Holocene deformation are apparent; the possibility of others is not straightforward. Radiometric ${ }^{14} \mathrm{C}$ ages of charcoal from the faulted colluvial-wedge deposit in the Upper Rainbow trench suggest fault events occurred around or just after 4,980-4,740 and 1,310-1,210 radiocarbon years $\mathrm{BP}$ ( $2 \sigma$ calibrated calendar ages of $\mathrm{BC} 3,747$ to 3,369 and AD 968 to 639, respectively).

\section{REFERENCES CITED}

Allen, V.T., 1934, Petrography and origin of the Fuller's Earth of southeastern Missouri: Economic Geology, v. 29, p. 590-598.

Anderson, E.M., 1951, The dynamics of faulting and dyke formation, with applications to Britain: Edinburgh, U.K., Oliver and Boyd, $206 \mathrm{p}$.

Antonellini, M.A., Aydin, Atilla, and Pollard, D.D., 1994, Microstructure of deformation bands in porous sandstones at Arches National Park, Utah: Journal of Structural Geology, v. 16, no. 7 , p. $941-959$.

Autin, W.J., Burns, S.F., Miller, B.J., Saucier, R.T., and Snead, J.I., 1991, Quaternary geology of the lower Mississippi Valley, in Morrison, R.B., ed., Quaternary nonglacial geology; Conterminous U.S., v. K-2 of The geology of North America: Boulder, Colo., Geological Society of America, p. 547-582.

Aydin, Atilla, 1978, Small faults formed as deformation bands in sandstone: Pure and Applied Geophysics, v. 116, p. 913-930.

Aydin, Atilla, and Johnson, A.M., 1978, Development of faults as zones of deformation bands and as slip surfaces in sandstone: Pure and Applied Geophysics, v. 116, p. 931-942.

Blum, M.D., Esling, S.P., and Guccione, M.J., 1995a, Introduction, in Esling, S.P., and Blum M.D., eds., Quaternary sections in southern Illinois and southeast Missouri: Guidebook to Midwest Friends of the Pleistocene, 42d Annual Meeting, Southern Illinois University, Carbondale, p. I-XV.

Blum, M.D., Robnett, P.C., and Guccione, M.J., 1995b, Selected aspects of the late Quaternary geology of the central Mississippi Valley, southeastern Missouri, chap. 8 of Esling, S.P., and Blum, M.D., eds., Quaternary sections in southern Illinois and southeast Missouri: Guidebook to Midwest Friends of the Pleistocene, 42d Annual Meeting, Southern Illinois University, Carbondale, p. 8.1-8.12.

Chiu, S.C., ed., 1991, CERI Quarterly Seismological Bulletin, January-March, 1991, v. 12, no. 1: Memphis (Tennessee) State University, Center for Earthquake Research and
Information, $101 \mathrm{p}$

Davis, G.H., 1999, Structural geology of the Colorado Plateau region of southern Utah, with special emphasis on deformation bands: Geological Society of America Special Paper 342, $157 \mathrm{p}$.

Doering, J.A., 1956, Review of Quaternary surface formations of Gulf Coast region: American Association of Petroleum Geologists Bulletin, v. 40, p. 1816-1862.

1958, Citronelle age problem: American Association of $\mathrm{Pe}$ troleum Geologists Bulletin, v. 42, p. 764-786.

1960, Quaternary surface formations of the southern part of the Atlantic Coastal Plain: Journal of Geology, v. 68, p. 182-202.

DuBar, J.R., Ewing, T.E., Lundelius, E.L., Jr., Otvos, E.G., and Winker, C.D., 1991, Quaternary geology of the Gulf of Mexico Coastal Plain, in Morrison, R.B., ed., Quaternary nonglacial geology; Conterminous U.S., v. K-2 of The geology of North America: Boulder, Colo., Geological Society of America, p. 583-610.

Farrar, Willard, and McManamy, Lyle, 1937, The geology of Stoddard County, Missouri: Missouri Geological Survey and Water Resources, 59th Biennial Report 1935-36, Appendix $6,92 \mathrm{p}$.

Farrar, Willard, Grenfell, D.S., and Allen, V.T., 1935, The geology and bleaching clays of southeast Missouri: Missouri Geological Survey and Water Resources, 58th Biennial Report 1933-34, Appendix I, $78 \mathrm{p}$.

Fisk, H.N., 1944, Geological investigation of the alluvial valley of the lower Mississippi River: Vicksburg, Miss., Mississippi River Commission, $78 \mathrm{p}$.

Frederiksen, N.O., Bybell, L.M., Christopher, R.A., Crone, A.J., Edwards, L.E., Gibson, T.G., Hazel, J.E., Repetski, J.E., Russ, D.P., Smith, C.C., and Ward, L.W., 1982, Biostratigraphy and paleoecology of lower Paleozoic, Upper Cretaceous, and lower Tertiary rocks in U.S. Geological Survey New Madrid test wells, southeastern Missouri: Tulane Studies in Geology and Paleontology, v. 17, no. 2, p. 23-44.

Frye, J.C., and Willman, H.B., 1960, Classification of the Wisconsinan Stage in the Lake Michigan glacial lobe: Illinois State Geological Survey Circular 285, 16 p.

Grimley, D.A., and Follmer, L.R., 1995, Illinoian and pre-Illinoian loesses and associated Sangamonian, Yarmouthian and older paleosols in unglaciated southwestern Illinois and eastern Missouri [abs.]: Geological Society of America Abstracts with Programs, v. 27, no. 6, p. A170.

Grohskopf, J.G., 1955, Subsurface geology of the Mississippi embayment of southeast Missouri: Missouri Geological Survey and Water Resources, 2d Series, v. 37, 133 p.

Grohskopf, J.G., and Howe, W.B., 1961, Cretaceous System, in Koenig, J.W., ed., The stratigraphic succession in Missouri: Missouri Geological Survey and Water Resources, 2d Series, v. 40, p. 123-124.

Guccione, M.J., Prior, W.L., and Rutledge, E.M., 1990, The Tertiary and Quaternary geology of Crowley's Ridge, in Guccione, M.J., and Rutledge, E.M., eds., Field guide to the Mississippi alluvial valley: Friends of the Pleistocene SouthCentral Cell, Fayetteville, Arkansas, p. 23-44.

Harrison, R.W., 1999, Geologic map of the Thebes quadrangle, Illinois and Missouri: U.S. Geological Survey Geologic Quadrangle Map GQ-1779, scale 1:24,000. 
Harrison, R.W., and Litwin, R.J., 1997, Campanian coastal plain sediments in southern Missouri and southern Illinois-significance to the early geologic history of the northern Mississippi Embayment: Cretaceous Research, v. 18, p. 687-696.

Harrison, R.W., and Schultz, A., 1994, Strike-slip faulting at Thebes Gap, Missouri and Illinois: Implications for New Madrid tectonism: Tectonics, v. 13, no. 2, p. 246-257.

Harrison, R.W., Litwin, R.J., Repetski, J.E., Mason, David, and Schultz, Art, 1996, Results of drilling in the English Hill area, Benton Hills, Scott County, Missouri: U.S. Geological Survey Open-File Report 96-44, 74 p.

Harrison, R.W., Palmer, J.R., Hoffman, David, Vaughn, J.D., Forman, S.L., McGeehin, J.P., and Frederiksen, N.O., 1997, Profiles and documentation of fault-exploration trenches in the English Hill area, Scott City 7.5-minute quadrangle, Missouri: U.S. Geological Survey Open-File Report 97-474, 111 p.

Harrison, R.W., Hoffman, David, Vaughn, J.D., Palmer, J.R., Wiscombe, C.L., McGeehin, J.P., Stephenson, W.J., Odum, J.K., Williams, R.A., and Forman, S.L., 1999, An example of neotectonism in a continental interior-Thebes Gap, Midcontinent, United States: Tectonophysics, v. 305, nos. $1-3$, p. 399-417.

Herrmann, R.B., 1993, New Madrid earthquake catalog display: Department of Earthquake and Atmospheric Sciences, St. Louis, Mo., Saint Louis University, 23 p.

Hildenbrand, T.G., and Hendricks, J.D., 1995, Geophysical setting of the Reelfoot rift and relations between rift structures and the New Madrid seismic zone, chap. E of Shedlock, K.M., and Johnston, A.C., eds., Investigations of the New Madrid seismic zone: U.S. Geological Survey Professional Paper 1538, p. E1-E30.

Isphording, W.C., and Lamb, G.M., 1971, Age and origin of the Citronelle Formation in Alabama: Geological Society of America Bulletin, v. 82, p. 775-780.

Jamison, W.R., and Stearns, D.W., 1982, Tectonic deformation of Wingate Sandstone, Colorado National Monument: American Association of Petroleum Geologists Bulletin, v. 66, no. 12, p. 2584-2608.

Jibson, R.W., and Keefer, D.K., 1993, Analysis of the seismic origin of landslides; Examples from the New Madrid seismic zone: Geological Society of America Bulletin, v. 105, p. 521-536.

Johnson, W.D., 1985, Geologic map of the Scott City quadrangle and part of the Thebes quadrangle, Scott and Cape Girardeau Counties, Missouri: U.S. Geological Survey Miscellaneous Field Studies Map MF-1803, 2 sheets, scale 1:24,000.

Koenig, J.W., 1961, Tertiary System, in Koenig, J.W., ed., The stratigraphic succession in Missouri: Missouri Geological Survey and Water Resources, 2d Series, v. 40, p. 125-130.

Lamar, J.E., and Reynolds, R.R., 1951, Notes on the Illinois "Lafayette" Gravel: Illinois State Geological Survey Circular 179 , p. 95-108.

Lamar, J.E., and Sutton, A.H., 1930, Cretaceous and Tertiary sediments of Kentucky, Illinois, and Missouri: American Association of Petroleum Geologists Bulletin, v. 14, p. 845-866.

Langenheim, V.E., and Hildenbrand, T.G., 1997, Commerce geophysical lineament-Its source, geometry, and relation to the Reelfoot rift and New Madrid seismic zone: Geological Society of America Bulletin, v. 109, no. 5, p. 580-595.

Leighton, M.M., and Willman, H.B., 1950, Loess formations of the Mississippi Valley: Journal of Geology, v. 58, p. 599-623.

Leonard, A.B., and Frye, J.C., 1960, Wisconsinan molluscan faunas of the Illinois valley region: Illinois State Geological Survey Circular 304, 32 p.

Madole, R.F., Ferring, C.R., Guccione, M.J., Hall, S.A., Johnson, W.C., and Sorenson, C.J., 1991, Quaternary geology of the Osage Plains and Interior Highlands, in Morrison, R.B., ed., Quaternary nonglacial geology; Conterminous U.S., v. K-2 of The geology of North America: Boulder, Colo., Geological Society of America, p. 503-545.

Marrett, Randall, and Allmendinger, R.W., 1990, Kinematic analysis of fault-slip data: Journal of Structural Geology, v. 12, no. 8, p. 973-986.

May, J.H., 1981, The up dip limit of Miocene sediments in Mississippi [abs.]: Geological Society of America Abstracts with Programs, v. 13, no. 1, p. 29.

McQueen, H.S., and Weller, J.M., 1939, Southwestern Illinois and southeastern Missouri: Kansas Geological Society, 13th Annual Field Conference Guidebook, $176 \mathrm{p}$.

Mellen, F.F., 1937, The Little Bear residuum: Mississippi Geological Survey Bulletin, v. 34, 36 p.

Moore, G.K., and Brown, D.L., 1969, Stratigraphy of the Fort Pillow test well, Lauderdale County, Tennessee: Tennessee Division of Geology, Report of Investigations 26, 1 sheet.

Naylor, M.A., Mandl, G., and Sijpesteijn, C.H.K., 1986, Fault geometries in basement-induced wrench faulting under different initial stress states: Journal of Structural Geology, v. 8, no. 7, p. 737-752.

Nelson, W.J., and Harrison, R.W., 1993, Post-Cretaceous faulting at the head of the Mississippi embayment [abs.]: Geological Society of America Abstracts with Programs, v. 25, no. 3, p. 69-70.

Olive, W.W., 1980, Geologic maps of the Jackson Purchase region, Kentucky: U.S. Geological Survey Miscellaneous Investigations Series Map I-1217, scale 1:250,000.

Palmer, J.R., and Hoffman, David, 1993, Possible late Quaternary faulting in the Benton Hills, southeastern Missouri [abs.]: Geological Society of America Abstracts with Programs, v. 25, no. 3, p. 72.

Palmer, J.R., Shoemaker, M., Hoffman, David, Anderson, N.L., Vaughn, J.D., and Harrison, R.W., 1997a, Seismic evidence of Quaternary faulting in the Benton Hills area, southeast Missouri: Seismological Research Letters, v. 68, no. 4, p. 650-661.

Palmer, J.R., Hoffman, David, Stephenson, W.J., Odum, J.K., and Williams, R.A., 1997b, Shallow seismic reflection profiles and geological structure in the Benton Hills, southeast Missouri: Engineering Geology, v. 46, p. 217-233.

Porter, D.A., and Guccione, M.J., 1994, Deglacial flood origin of the Charleston alluvial fan, lower Mississippi alluvial valley: Quaternary Research, v. 41, no. 3, p. 278-284.

Potter, P.E., 1955a, The petrology and origin of the Lafayette Gravel; Part 1, Mineralogy and petrology: Journal of Geology, v. 63 , p. $1-38$.

1955b, The petrology and origin of the Lafayette Gravel; Part 2, Geomorphic history: Journal of Geology, v. 63, p. $115-132$.

Pryor, W.A., 1960, Cretaceous sedimentation in upper Mississippi embayment: American Association of Petroleum Geologists Bulletin, v. 44, no. 9, p. 1473-1504. 
Pryor, W.A., and Ross, C.A., 1962, Geology of the Illinois parts of the Cairo, La Center, and Thebes quadrangles: Illinois State Geological Survey Circular 332, 39 p.

Ramsay, J.G., and Huber, M.I., 1987, The techniques of modern structural geology: Orlando Florida, Academic Press, v. 1, 700 p.

Russell, E.E., and Parks, W.S., 1975, Stratigraphy of the outcropping Upper Cretaceous, Paleocene, and lower Eocene in western Tennessee (including descriptions of younger fluvial deposits): Tennessee Division of Geology Bulletin 75, 53 p.

Saucier, R.T., 1964, Geological investigation of the St. Francois Basin, lower Mississippi Valley: U.S. Army Engineer Waterways Experiment Station Technical Report 3-659, scale $1: 62,500$.

1968, A new chronology for braided stream surface formation in the lower Mississippi Valley: Southeastern Geology, v. 9 , no. 2, p. 65-76.

1974, Quaternary geology of the lower Mississippi Valley: Arkansas Archeological Survey, Archeological Research Series, v. 6, p. 26.

1994, Geomorphology and Quaternary geologic history of the lower Mississippi Valley, Volume 1: Vicksburg, Miss., U.S. Army Corps of Engineers, Mississippi River Commission, 398 p. (Available from National Technical Information Service, Springfield, Va., no. AD-A299 154/5NEG.)

Sims, J.D., 1972, Petrographic evidence for volcanic origin of part of the Porters Creek Clay, Jackson Purchase region, western Kentucky: U.S. Geological Survey Professional Paper 800-C, p. C39-C51.

Sohl, N.F., and Mello, J.F., 1970, Biostratigraphic analysis, in Owens, J.P., Minard, J.P., Sohl, N.F., and Mello, J.F., Stratigraphy of the outcropping post-Magothy Upper Cretaceous formations in southern New Jersey and northern Delmarva Peninsula, Delaware and Maryland: U.S. Geological Survey Professional Paper 674, p. 28-55.

Steel, R.J., Gjelberg, John, Helland-Hansen, William, Kleinspehn, Karen, Nottvedt, Arvid, and Rye-Larsen, Morten, 1985, The Tertiary strike-slip basins and orogenic belt of Spitsbergen, in Biddle, K.T., and Christie-Blick, Nicholas, eds., Strike-slip deformation, basin formation, and sedimentation: Society of Economic Paleontologists and Mineralogists Special Publication 37, p. 339-359.

Stewart, D.R., 1942, The Mesozoic and Cenozoic geology of southeastern Missouri: Rolla, Mo., Missouri Geological Survey and Water Resources, unpub. manuscript.

Stewart, D.R., and McManamy, Lyle, 1944, Early Quaternary or late Tertiary folding in the vicinity of Commerce, Scott County, southeastern Missouri: Rolla, Mo., Missouri Academy of Science, unpub. internal report.

Stover, C.W., and Brewer, L.R., 1991, United States earthquakes, 1985: U.S. Geological Survey Bulletin 1954, 170 p.

Stringfield, V.T., and LaMoreaux, P.E., 1957, Age of Citronelle Formation in Gulf Coastal Plain: American Association of Petroleum Geologists Bulletin, v. 41, no. 4, p. 742-746.

Sylvester, A.G., 1988, Strike-slip faults: Geological Society of America Bulletin, v. 100, p. 1666-1703.

Sylvester, A.G., and Smith, R.R., 1976, Tectonic transpression and basement-controlled deformation in the San Andreas fault zone, Salton Trough, California: American Association of Petroleum Geologists Bulletin, v. 60, no. 12, p. 2081-2102.

Thompson, T.L., 1991, Paleozoic succession in Missouri; Part 2, Ordovician System: Missouri Department of Natural Resources, Division of Geology and Land Survey, Report of Investigations $70,282 \mathrm{p}$.

Tschudy, R.H., 1965, Palynological investigations in the Upper Cretaceous and Tertiary of the Mississippi embayment regionI: Washington, D.C., U.S. Geological Survey Open-File Report, $63 \mathrm{p}$.

Varnes, D.J., 1978, Slope movement types and processes, in Schuster, R.L., and Krizek, R.J., eds., Landslides; Analysis and control: Transportation Research Board, National Research Council, Special Report 176, p. 11-33.

Weller, J.M., 1940, Geology and oil possibilities of extreme southern Illinois: Illinois State Geological Survey Report of Investigations $71,71 \mathrm{p}$.

Willman, H.B., and Frye, J.C., 1970, Pleistocene stratigraphy of Illinois: Illinois State Geological Survey Bulletin 94, 204 p.

Willman, H.B., Atherton, E., Buschbach, T.C., Collinson, C., Frye, J.C., Hopkins, M.E., Lineback, J.A., and Simon, J.A., 1975, Handbook of Illinois stratigraphy: Illinois State Geological Survey Bulletin 95, $261 \mathrm{p}$.

Zoback, M.L., 1992, First- and second-order patterns of stress in the lithosphere; The world stress map project: Journal of Geophysical Research, v. 97(B8), p. 11,703-11,728.

Zoback, M.L., and Zoback, M.D., 1980, State of stress in the conterminous United States: Journal of Geophysical Research, v. 85 , p. $6,113-6,156$.

1989, Tectonic stress field of the continental United States, in Pakiser, L.C., and Mooney, W.D., eds., Geophysical framework of the continental United States: Geological Society of America Memoir 172, p. 523-539. 